\title{
Publisher Correction: Molecular analysis of primary melanoma Tcells identifies patients at risk for metastatic recurrence
}

Wiebke Pruessmann, Julie Rytlewski D, James Wilmott (D, Martin C. Mihm Jr, Grace H. Attrill, Beatrice Dyring-Andersen, Paul Fields (D), Qian Zhan, Andrew J. Colebatch, Peter M. Ferguson, John F. Thompson (D), Klaus Kallenbach, Erik Yusko, Rachael A. Clark, Harlan Robins, Richard A. Scolyer (D) and Thomas S. Kupper (D)

Correction to: Nature Cancer https://doi.org/10.1038/s43018-019-0019-5, published online 20 January 2020.

In the version of this article initially published, the TCR region is described incorrectly (TCR $\beta$-cell) in the third sentence of the third paragraph. The correct phrase is 'TCR $\beta$-chain'. The error has been corrected in the HTML and PDF versions of the article.

Published online: 17 March 2020

https://doi.org/10.1038/s43018-020-0049-z

๑ The Author(s), under exclusive licence to Springer Nature America, Inc. 2020 